\title{
Experiences of high school principals in managing the academic deviancy
}

\author{
Armand James A. Vallejo * \\ University of Mindanao, Davao, Philippines
}

\author{
Keywords \\ School principal \\ Deviant \\ Management \\ Phenomenology \\ University of Mindanao \\ Received:3 October 2019 \\ Accepted: 6 November 2019 \\ Published: 23 December 2019
}

\begin{abstract}
This phenomenological study explored the experiences of high school principals with students with derogatory records and provided valuable insights to high school principals in terms of managing the academic deviancy of students with derogatory papers. Using purposive sampling, the researcher identified public and private high school principals as participants of the study. The semi-structured interview guide was validated and used in this study to generate data from the participants. Results revealed that the experiences of high school principals in dealing with students with derogatory records are feeling sorry for what happened to them, disrespecting by the students and parents, encountering bully students, comforting students with a family problem, giving pieces of advice and opportunities, and conferencing with parents. Further, school principals met students who misbehave, gang members, fighters, liars, and students who cut classes. These students who have derogatory records are also the victim of their environment. They were just the receiver of the action shown to them. The management style of the principal is democratic. They perform such a manner through delegating, empowering, consulting, and empathizing. However, the principal's impact on the students with derogatory records is a fear, strict, threat, not visible, and oblige. Thus, principals should implement rules which are agreeable by the subordinate.
\end{abstract}

(C) 2019 The Author(s). Published by TAF Publishing

\section{INTRODUCTION}

The duty and responsibility of the principal are to govern the school. It is through managing and updating the school progress, particularly the school achievement and behaviors of his subordinates and the students. There are instances that the subordinates and students do not follow school policy and regulations for personal reasons. The roles of principals, in this case, are at a high stake in developing a high-quality school (West Ed, 2008; Knapp et al., 2003). Hallinger and Heck (1996) accounted that the connection of principals and students towards academic achievement and behavior is lesser when the educational relationship is absent. It leads to a showing of inappropriate behavior in the classroom.

However, it may turn into a positive output an effect when the school principals go over with the operations. It is through motivating teachers and students, identi- fying and articulating vision and goals, developing highperformance expectations, fostering communication, allocating resources, developing organizational structures to support instruction and learning, and addressing students' behavioral problems (Aldhafeeri \& Alajmi, 2017; Leithwood, Seashore, Anderson, Wahlstrom, et al., 2004).

Some students commit violent crimes in the school (Mbuthia, 2013). It results from disobeying the school rules and regulations, lazy and disobedient to parents, destroying public properties, and the like and tagged as deviant. They drop and leave their academics undertakings (Osalusi \& Oyinloye, 2014). Deviant behaviors observe to the youths who are reportedly using illegal drugs and abusing alcohol intake. A manifestation of disobeying the norms (Dichtl, 2003; Gupta \& Shrestha, 2018; Peris \& Emery, 2004). The roles of the principals take its place. It is to maintain the instructional quality and disciplinary procedure

${ }^{*}$ corresponding author: Armand James A. Vallejo

†email: armandjamesvallejo23@gmail.com 
of school (Christie, Thompson, \& Whiteley, 2009; Canivel, 2010; Harris \& Hathorn, 2006; Horng, Klasik, \& Loeb, 2010; Wahlstrom, Seashore, Leithwood, \& Anderson, 2010).

The deviant disturbed the normal behavior of the society. The instruction and operations disrupted (Cooperkline, 2009). Thus, this is when principals' managing style becomes very significant as he leads the school community.

\section{LITERATURE REVIEW}

\section{Endeavours of School Principals towards Deviant}

Students who are physically, mentally, and emotionally disturbed cannot perform well in the classroom. It compromises the readiness to learn and makes some unnecessary actions in the school community (Ostrosky, Jung, Hemmeter, \& Thomas, 2003). These kinds of behaviors disrupt the teaching and learning process (Ishtiaq, 2009). Thus, Nayak (2010) recommended that high school principals let the students reflect on it to develop self-discipline.

The rules and routines provided to the students work well in the classroom (Edwards, 2004; Luczak \& Kalbag, 2018). It develops a positive school environment with the guidance of the school principals Ostrosky et al. (2003). The school principals create school conditions wherein students may feel safe and learn holistically. Canter and Canter (2001) stressed that schools must have goals. It includes create and maintain a highly supportive learning environment and second, to promote a safe school community so that students' interest, motivation, and involvement in the learning process is maintained.

The management strategies of Ingersoll and Smith (2003) such as reflecting on student development needs, creating a supportive physical environment, creating a cooperative learning environment, teaching and maintaining rules and procedures, managing classroom activities effectively, promoting a sense of cooperation among students, using appropriate classroom management style are suggested. Blankstein, Houston, and Cole (2010), Jones (2000), Santrock (2017) explained that school principals should know where to focus on their work. The clear mission or purpose and identify goals are among the top priorities. It is to let the stakeholders, especially the students, understand (McIver, Kearns, Lyons, \& Sussman, 2009; Suwanwong, 2017).

The contributions of the school leaders to the learning of the students depend on how they take part in the organization (Leithwood et al., 2004). The high school principals are making the lives of the students in different ways. Moreover, stakeholders like parents, students, and subordinates are required to implement a change in process in the learn- ing development to assess the effectiveness and leadership of the instructional and administrative leadership (Blase, 2001; Cooper, 2011; Hoy \& Miskel, 1987; Hoy \& TschannenMoran, 2007).

\section{Students with Derogatory Records}

Students who showed deviancy are normal, culturally, and socially accepted. One indicator of this acceptance is the sociological pressure like poverty. Students tend to violate social norms and tag as informal violators of the social norms (Cooperkline, 2009; Rao, 2011).

Students who exhibit challenging behaviors like self-injury, aggression, and sexualized behavior increased the risk of academic failure, delinquency, dropping out, gang membership, and adult incarceration. These rooted in the biological, environmental, psychological, and or social factors that are significant in educational and social issues. The high school principals challenged them from the exclusion of the students from their learning. It includes suspension, expulsion, or other forms of exclusionary practices (Dunlap et al., 2006).

The Labeling Theory of Lemert (1967) explained better the magnification of deviance. Students labeled themselves as deviant when they view themselves as one and consistently engaging in an act (Cullen \& Wilcox, 2010; Merriam \& Tisdell, 2015; Seunarinesingh, 2011).

Anderson (2012) believed that deviants are emotionallydisturbed individuals. They characterized the behavioral or emotional responses coming from the different appropriate age, cultural, or ethnic norms that adversely affect educational performance, including academic, social, vocational, or personal skills. It leads to the occurrence and be a member of the gangs and the like (Kimani, 2010; Pizzuro, 2001). Furthermore, Kikuvi (2009) states students with abusive family members experience a high rate of parental problems. It causes poor parent-child attachment leads to a lack of commitment to family gathering activities, and doing illegal drug undertaking (Nayak, 2010; Peris \& Emery, 2004). These occurrences could result in bullying. It is the most common form of violence in our society. According to Kinnes (2000), verbal abuse and harassment, followed by social isolation and derogatory comments about physical appearance, are a common form of bullying. It is frequently involve teasing and social exclusion, but may also include physical violence, threats, theft, sexual and racial harassment, and public humiliation (Shellard, 2002). 


\section{METHOD}

This study employed qualitative phenomenology congruent with the philosophical assumption ex ontological which discusses the nature of social reality and its characteristics (Creswell \& Poth, 2016; Merriam \& Tisdell, 2015; Osalusi \& Oyinloye, 2014; Velez, 2008).

The key informants in this study are the two principals from different types of school-public and private using purposive sampling (Bernard, 2017; Bryman, 2003; Hesse-Biber, 2010; Lincoln, 1985). They are both 8 years in service.

The interviews were audio-recorded. Permission to conduct was granted (Boyce \& Neale, 2006). Thus an in-depth interview was employed to the informants. The interviews were transcribed for analysis (Lemert, 1967). Lastly, the trustworthiness of the study was employed Lincoln (1985). It validates the four components, such as credibility, confirmability, transferability, and dependability.

\section{RESULTS AND DISCUSSION}

\section{Experiences of the Key Informants Managing Students with Derogatory Records}

Disrespecting by the Students and Parents. "What you see is what you believe." This was shown in front of the school principal when the school coordinator was humiliated towards her student and parent. As a school principal, it is her responsibility to solve the problem within the school community. Parents should act accordingly as to how to solve the problem.

The parent here shows disrespecting the school principal in front of her. The principal is expected to be respected in the school premise. However, she provoked by the parent of the student who happened to have a problem in her school academic performance. Disrespecting the high school principal shows the kind of students they have. It reflects on how she manages the school community. The disappointment of the high school principal directed her to consult a lawyer.

I pitied my coordinator. Worst, worst that she had done. It's a parent towards my coordinator It was hurt to worth to shock on our part because we were both unguarded and "ma'am... not", NO! she said, SIT! And I was around. I seem... and we were all sort shock and and then we consulted a lawyer (P1, L3-7)

The high school principals know where and what to focus. It is essential in their behalf to clear up the mission or purpose of the school. It aligns with the identified goals. Thus, stakeholders communicated the progress of the school in a meaningful way. The purpose and goals were understood (McIver et al., 2009).

The school principal's role is to manage the School. It is shown how he deals with those students who have derogatory records. Patience is tested. The management style shows, and the commitment and determination reveal if the students violate school policies and regulations. Those students who disrespect the high school principal needs special attention. Shouting, fighting, and kicking are forms of disobedience towards the high school principal. These may have considered as a minor offense, yet the impact to the community is very horrible as stated by the School Principal 2:

So far for the 8 years in my service as principal, I don't observe or experience that there were killings inside the school. Only shouting fighting like boxing, kicking (P2, L14-15)

The contributions of the leader to the academic performance of the students depend on how they deal with the school community. The high school principal spends time and attention in every detail of the students' actions and behavior (Leithwood et al., 2004).

\section{Encountering Bully Students}

Encountering students with derogatory records measure how good a manager you are. It tests the capabilities of the school principal in handling these individuals. It is not easy to manage these kinds of students because it needs to follow the protocol. On the other hand, the school principal shared his experiences in handling those students who have derogatory records. He explained that these individuals should refer to the school prefect of discipline for disciplinary action and sanctions. Also, the high school principal delegates his task to make things easy and to focus more on the other responsibilities.

Example gangsterism. Yes, in school X, ahm bullying which is common this time, theft, especially in Y High School. Fighting, shouting inside the classroom. But there is a specific office to solve that problem; the prefect of discipline. So every time students commit mistakes, they endorse by the adviser to the prefect of discipline (P2, L8-12).

Ostrosky et al. (2003) pointed out that the role of the high school principal is essential to the development of the students. It gives a positive school environment. The principal can create such conditions in the school to let the students feel that they are safe and learn how to work together effectively (Canter \& Canter, 2001).

Bullying is the most common issue in school nowadays. Students tend to bully their classmates because they were once a victim of bullying. The school principal shared her experiences in encountering those students who have derogatory records. We may say that bullying happens only in school, 
yet we are wrong. The school principal found out that aside from the students who bullied their classmates, his grandfather also bullied him. The school principal was disappointed because she was expecting that the family member will help her in addressing this kind of problem. However, this made her exert more effort in resolving the issue of bullying inside the school premise.

We found out, last year we found out that it's the grandfather who has been bullying the kid. So sad, and then also yeah bullying for example we have worst case of bullying (P1, L27-28).

Ishtiaq (2009) claimed that when the classroom instruction disrupted by harmful behavior, it compromises the teaching and learning process.

\section{Conferencing with Parent}

The school principal informed the parents about the activity of their students. She contacted the parents by sending a message on their Facebook account, especially those parents who are in abroad. The attitude conveys a strong relationship between the school subordinate and stakeholders. It strengthens the bond of belongingness of individuals in the school community. The school principal shared this based thru her statement. With the parents naman we talk to them. If they won't come for a conference I would personally PM (private message) them through Facebook (P1, L50).

The key constituent in achieving school improvement is through effective school leadership. It accepts social responsibility as a leader in the community. Furthermore, it is an opportunity for the high school principal to make a difference in society (Hoy \& Tschannen-Moran, 2007).

Students who are late in their classes need to be disciplined by the school principals, especially those who have derogatory records. It is a way of informing the parents about the performance of their children. With this, the parents may be called and talked with the school principals. It is the best thing to do with the high school principals. As express by the Principal 2:

For those who come late, you use gate 2. And you have to write your name in the log book. And that name should be transmitted to your adviser, curriculum head and your parents will be called. Informing your parents that you are late for a number of days. Discipline talaga (P2, L42-46).

Edwards (2004) supported the construct that high school principals should make a structure in providing students with fair organization and interaction. It includes the school rules and daily routines through written, and oral forms.

\section{Comforting Students with Family Problems}

Showing concerns to the students may uplift their interest in the academic undertakings. On the one hand, teachers show empathy to the student to encourage them to perform better in the classroom discussion. On the other hand, the high school principal orients himself in solving any cases may help the students with derogatory records committed. These two individuals have a professional commitment to their profession through disciplining and empathizing with the students. Comforting and encouraging deviants are ways of lifting confidence. Performing well in the classroom is an indicator that these deviants are part of the instruction. It shows belongingness and acceptance among other students. They are shy and tend to remain silent as they have problems that keep them anxious. However, when somebody comforts them, they can feel secure. As I interviewed the Principal 1, she expresses herself on how she comforted students as stated below:

And then, there's even one seems he has a secret then he was a third year high school able to share to a teacher why I am getting bad? Because my grandmother wants me to marry to ... just like that story. I talk with the grandfather I talk with the grandmother that he is trying to show that he has a deviant attitude... He has what..... I need to be bad so that the girl wouldn't like me... yes like that (P1, L119-122). Blase (2001) stated that trust is a powerful construct in lifting the academic spirit of the students. It improves the micro-society and self-confidence of the students because deviants need special attention.

The students caught in their wrongdoings may feel embarrassed and not accepted in the community. The students become blatant when provoke. It means of joining any gang's organizations and commit school violation. However, Principal 2 shows concern to the students who violated the rules and policies of the school. Students feel a sense of belongingness, knowing that they are deviant. They seek aa special attention from their peer.

I caught one, there, their lips are very red. Using the very red lipstick, it signifies that they belong.Then, I confronted them on what they feel and answered they are humiliated. Students should be accepted in the society, they should not be humiliated in front of the people. Here in school, I announce, if you are involve in gangsterism, and violated the policy of the shool, the tendency, you will be penalized (P2, L83-87).

When the high school principal comforts the deviants, the trust relationship is at stake (Hoy \& Miskel, 1987). The risk and expectation abound when trust is an issue. Meanwhile, these deviants are always put into consideration of not ex- 
pecting too much from them. They may perform specific duties yet, and their well-being depends on how they filled in certain obligations.

\section{Feeling Sorry for What Happened to Them}

. An intensive investigation happened in identifying the deviants. It is in line with the protocols posted in every organization. The high school principal considers it like an organized manner of investigating the case. However, some principals are kindhearted. They are emphatic and feel the feelings of their students. It is because deviants need care and love when their emotional aspect is in trouble. The high school principal approaches these deviants in a motherly manner. She comforted them through embracing, crying with them, and hugging.

Kay I would feel man gud, I cannot have myself but feel the feelings of others. I would cry with them. Some of my students, I cry with them whenever they shared their stuff to me, mga family matters. I cry with them and I would ask them "is it okay if imbrace you?" I do that "yes teacher" although there was one Australian. FilipinaAustralian, hadluk siya...takot sya because she's been rebelling and she's always and I was felt sorry to her. One thing to be out of the campus and when I try to counsel and when I try to listen to her, Oh my God, she shared her story of abuse by her own father. And so finally, when I said "is it okay if I hug you?" takot siya (P1, L131138).

Socialization is a way of achieving the purpose of school management. It gives students a positive outlook on life. The high school principal, on her end, desires the positivity towards students' attitudes. When the high school principal fails in sympathizing with the students, she may find other means to arrest the disturbance happened inside the classroom. Planning and strategies with an expert could help. Ingersoll and Smith (2003) provided strategies to help the high school principal. It includes reflecting on student development needs, creating a supportive physical environment, creating a cooperative learning environment, teaching and maintaining rules and procedures, managing classroom activities effectively, promoting a sense of cooperation among students, and using appropriate classroom management style.

The crucial stage in the students' life is at the high school level. Temptations are everywhere, and self-composure is at risk. The emotional aspect of the students is unstable at this stage. Students are making love affairs with their classmates or schoolmates. The high school principal observed this happening in every corner of the classroom. However, it concludes that self-respect and discipline are ways of mit- igating such actions. Thus, constant monitoring helped the principal in assessing the academic performance of the students.

Furthermore, the students who have derogatory records and who are in a relationship are bound to separate from each other. The school principal may feel sorry to this, but of course, for the sake of their studies, Principal 2 needs to perform his responsibilities.

There activity is to wrestle. They will wrestle those who won't follow them or have a sexual intercourse. Of course what shall I do, I need to stop them. So, mostly, what I did is that they are subject for monitoring. I will let them transfer out for them to be separated from each other. One should be separated but if they want to go together, let them. I pitty on their parents (P2, L88-93).

Showing pity towards deviants is not bad. It has a process on which they can comfortably express themselves. The high school principal should have communicative leadership. It helps the students to voice out their feelings (Eriksen, 2001).

\section{Giving them Advices and Opportunities}

The welfare of the students is the concern of the Principal 2. Pieces of advice and opportunities to keep away from negativities have a significant impact on them. It is not possible without the help of the parent. It gives proper guidance. We need to implement the child protection policy especially in the school that we are implementing the "child friendly school system". That we have to understand the behaviour of the students. We have to re-modify the behaviour of the students as well as modifying or give advices to the students who are involve in this problem. As well as, inform the parents with regard to the behaviour of their children (P2, L17-20).

The degree of achievement of the students takes place between the communication of the students and the high school principal. The clear instructions and responses of the students grasp the needs of the students. Nayak (2010) elaborated that high school principal gives students time to reflect and realize their wrongdoing behavior. It develops self-discipline among others.

It is challenging to talk with the students with derogatory records. However, without a second thought, the high school principal talked directly to them to resolve issues. There are a series of talks and counseling that happened. It revealed that some deviant students are intrapersonal. They expressed their emotions in social media as a platform of their identity.

As a principal, I would talk, series of talks for example I had 
a series of talk with our students and then we give counselling... we give counselling, we give them time to breathe in and breathe out and we just know that they are brilliant actually with different programs inputted by the parents or by the social media (P1, L46).

The high school principal is responsible for the actions of the students. There are varieties of means to input the responsibilities. It includes talking to students, visiting classrooms, talking to faculty about the progress of the students' academic performance, or it may involve designing sophisticated information systems to check on the quality of performance (Blankstein et al., 2010).

\section{Showing Concern to the Students}

The experiences of the school principal in handling academic deviancy marked its determination and kind of leadership. Letting the students feel that they are taking care of someone. It manifested in the strict implementation of the school policies.

If they will complain, I will let them out. Because I am doing this for them to attend their classes because their first of class starts at 7:30 am. If they arrived at 8 o'clock, they are late for 30 minutes already. What will happen to them? So they failed. So, I need to consult them. Inform them during flag ceremony (P2, L48-52).

The Department of Education keeps its promise to provide quality education to all. The school principal realizes its vision and mission in the school community by embodying the school rules and policies. Students with derogatory records are learning to walk independently following the school policies. It requires critical thinking painstakingly (Cooper, 2011).

The school principal is afraid of allowing the students to go out of the school premises during the class hours. It is because the high school principal is responsible for all of the actions of the students. However, deviants defy school policies. They escaped together with their allies. They want to be praised by other students because they believe that they are famous and influential on the campus. The principal tightens the security in the school. Students who caught violating the rules are scheduled for the conference.

Because we do not normally allow our students to go out during lunch break and there's this one prominent a high school student, whenever she goes out; since she will be fetch by a hummer, hummer only, oh my God, she would bring with her allies. Three to four allies or classmates and then we have to confront; why do you want to bring your classmates? There's only one excuse letter and that's for you, we cannot allow them, then they escape. We have to talk again, and again, and agin, conference together with the parents (P1, L95-98).

The high school principals are expected from them the readiness to respond to the learning needs of the students. There should have constant monitoring of the teaching and learning process to have an engaging school environment (Santrock, 2017). Some of these are by watching them closely, giving feedback to correct undesirable behaviors and to praise for good acts as the communication pattern (Jones, 2000).

\section{Students with Derogatory Records}

There are a lot of problems in school. One of which is the behavior of students who happened to be misguided by their parents. They express themselves by committing such actions as consciously and unconsciously. It revealed in this study that deviants are gangsters, misbehaving students, fighters, and liars are the major classifications of students who commit a violation in the school premise.

\section{Gangster}

The first deviant identified with the derogatory record is a gangster. A gangster threatens its surroundings through its composure and physical appearance of the subject. As noted, gangs appear to choose the arrival and departure times of educators and learners and wait for learners at the school gate. They terrorize educators, learners, and parents.

Gangsterism inherently accepted in society. It defines its identity concerning the social world. It modifies its world of loyalty, brotherhood, and universality towards beliefs (Kinnes, 2000).

\section{Students who Misbehave}

The second student with a derogatory record that school principals' stressed out is the student who misbehaves inside the classroom. In every school, rules and regulations are set to achieve harmony and peace towards each other. But this can be hampered when students misbehave. Misbehavior is an act of not following the instruction given by the authority. It is also an act of doing something wrong with another person that causes conflict.

Some students are disturbed in different ways during the class discussion. It includes difficulty staying in their seats, talk out of turn, and get into fights in learning with their classmates. It is challenging for those who are behaving in the class. Meanwhile, McKee, Rivkin, and Sims (2010) pointed out that behaviors like that have a negative impact on the students' achievement. 


\section{Fighter}

The third student with the derogatory record that school principals' stressed out is the students who tend to fight with other students. It emotionally expressed the difficulty in handling the deviants. There were times when students shouting at their classmates, kicking, and boxing with their peers. Fighting, shouting inside the classroom (P2, L10). Only shouting, fighting like boxing, kicking (P2, L15) Classroom teaching and learning are disrupted by negative behavior daily. Freiberg, Huzinec, and Templeton (2009) believe that within the classroom, the reaction of the student disturbs the learning environment. It has a rippling effect by influencing the disruptive individual, his or her classmates, the school, and subsequently, near and far communities, steal valuable teaching and learning time. It follows, therefore, that if the level of indiscipline continues to rise, there can be severe damaging effects on the performance of students.

\section{Liar}

In the academe, lying is a part of academic dishonesty. Academic dishonesty in many different ways includes cheating, not citing a source, and changing another's words around to make it look as though they were one's idea (Regev et al.,
2002).

However, Dichtl (2003) noted that institutions should make their students conduct a thorough and comprehensive honor code. It outlines the integrity and expectation, definitions of improper and proper conduct, and also spells out the penalties of violations. Students quickly confront their peer's behavior on academic dishonesty if they made to understand the institution's expectations. Accordingly, the main reasons for the student to avoid academic dishonesty are obedience to the rules and avoidance of penalties (Boyce \& Neale, 2006).

\section{CONCLUSION}

Experiences are defined based on the problem occur. School principals shared their experiences in handling students with derogatory records. It is in a nutshell that deviant students drastically perform violent reactions against the norm and social welfare. These deviants are victims of circumstances portraying some negatives behaviors.

\section{LIMITATIONS AND RECOMMENDATIONS}

This study has some limitations, therefore scholars are advised to replicate this study with more robust research designs and enhance the credibility of these findings.

\section{REFERENCES}

Aldhafeeri, F. M., \& Alajmi, M. R. (2017). Towards excelled mobile learning implementation in Kuwait university: Aspects and obstacles of use and non-use. Journal of Advances in Humanities and Social Sciences, 3(5), 264-281. doi:https:// doi.org/10.20474/jahss-3.5.3

Anderson, S. R. (2012). Psycho-educational processes as strategies for students presenting with emotional and behavioural disorders. American International Journal of Contemporary Research, 2(7), 99-108.

Bernard, H. R. (2017). Research methods in anthropology: Qualitative and quantitative approaches. New York, NY: Rowman \& Littlefield.

Blankstein, A. M., Houston, P. D., \& Cole, R. W. (2010). Data-enhanced leadership. Thousand Oaks, CA: Corwin Press.

Blase, J. (2001). Empowering teachers: What successful principals do. Thousand Oaks, CA: Corwin Press.

Boyce, C., \& Neale, P. (2006). Conducting in-depth interviews: A guide for designing and conducting in-depth interviews for evaluation input. Watertown, MA: Pathfinder International.

Bryman, A. (2003). Encyclopedia of social science research methods 8. New York, NY: Sage Publications.

Canivel, L. D. (2010). Principals' adversity quotient: Styles, performance, and practices (Unpublished master's thesis). University of Philippines, Quezon City, Philippines.

Canter, L., \& Canter, M. (2001). Assertive discipline: Positive behavior management for today's classrooms. Seal Beach, CA: Canter.

Christie, K., Thompson, B., \& Whiteley, G. (2009). Strong leaders, strong achievement: Model policy for producing the leaders to drive student success (Technical report). Education Commission of the States, Denver, CO.

Cooper, R. (2011). The breaking of nations. London, UK: Atlantic Books Ltd.

Cooperkline, J. (2009). School absenteeism, disruptive classroom behavior, and negative family processes in a sample of courtinvolved youth (Unpublished doctoral dissertation). The Ohio State University, Ohio, $\mathrm{OH}$.

Creswell, J. W., \& Poth, C. N. (2016). Qualitative inquiry and research design: Choosing among five approaches. London, UK: Sage publications. 
Cullen, F. T., \& Wilcox, P. (2010). Encyclopedia of criminological theory. London, UK: Sage.

Dichtl, J. (2003). Teaching integrity. The History Teacher, 36(3), 367-373.

Dunlap, G., Strain, P. S., Fox, L., Carta, J. J., Conroy, M., Smith, B. J., ... McCart, A. (2006). Prevention and intervention with young children's challenging behavior: Perspectives regarding current knowledge. Behavioral Disorders, 32(1), 29-45. doi:https://doi.org/10.1177/019874290603200103

Edwards, C. H. (2004). Classroom discipline and management. New York, NY: John Wiley and Sons.

Eriksen, E. O. (2001). Leadership in a communicative perspective. Acta Sociologica, 44(1), 21-35. doi:https://doi.org/ $10.1177 / 1742715013509396$

Freiberg, H. J., Huzinec, C. A., \& Templeton, S. M. (2009). Classroom management a pathway to student achievement: A study of fourteen inner-city elementary schools. The Elementary School Journal, 110(1), 63-80. doi:https://doi.org/ $10.1086 / 598843$

Gupta, V. P., \& Shrestha, D. B. (2018). Increasing trend in rape cases in Asian Subcontinent: A review. Pacific Journal of Science and Technology, 05(19), 34-40.

Hallinger, P., \& Heck, R. H. (1996). Reassessing the principal's role in school effectiveness: A review of empirical research, 1980-1995. Educational Administration quarterly, 32(1), 5-44. doi:https://doi.org/10.1177/ $0013161 \times 96032001002$

Harris, S., \& Hathorn, C. (2006). Texas middle school principals' perceptions of bullying on campus. Nassp Bulletin, 90(1), 49-69. doi:https://doi.org/10.1177/0192636505284527

Hesse-Biber, S. (2010). Analyzing qualitative data: With or without software. Boston, MA: Boston College Press.

Horng, E. L., Klasik, D., \& Loeb, S. (2010). Principal's time use and school effectiveness. American Journal of Education, 116(4), 491-523.

Hoy, W. K., \& Miskel, C. G. (1987). Educational administration: Theory, research, and practice. California, CA: Random House Trade.

Hoy, W. K., \& Tschannen-Moran, M. (2007). The conceptualization and measurement of faculty trust in schools. Essential ideas for the Reform, 5(8), 87-114.

Ingersoll, R. M., \& Smith, T. M. (2003). The wrong solution to the teacher shortage. Educational Leadership, 60(8), 30-33.

Ishtiaq, H. (2009). Teachers can make a difference. Retrieved from https://bit. ly/2C5INlq

Jones, F. (2000). Tools for teaching. Santa Cruz, CA: Jones and Associates.

Kikuvi, R. (2009). Determination of juvenile delinquency development among pupils in machakos rehabilitation schools (Unpublished maters thesis). Kenyatta University, Nairobi, Kenya.

Kimani, A. (2010). Influence of family structure on juvenile delinquency in nakuru children's remand home. Retrieved from https://bit.ly/37AV5he

Kinnes, I. (2000). From urban street gangs to criminal empires: The changing face of gangs in the Western Cape. Pretoria, South Africa: Institute for Security Studies.

Knapp, M. S., Copland, M. A., Ford, B., Markholt, A., McLaughlin, M. W., Milliken, M., \& Talbert, J. E. (2003). Leading for learning sourcebook: Concepts and examples. London, UK: ERIC.

Leithwood, K., Seashore, K., Anderson, S., Wahlstrom, K., et al. (2004). Review of research: How leadership influences student learning (Unpublished master's thesis). Center for Applied Research and Educational Improvement, University of Minnesota, Minneapolis, Minnesota.

Lemert, E. M. (1967). Human deviance, social problems, and social control. Englewood Cliffs, NJ: Prentice-Hall.

Lincoln, G. Y. S., E. G. (1985). Naturalistic inquiry. Beverley Hills, CA: Sage.

Luczak, C., \& Kalbag, A. (2018). The appropriateness and effectiveness of cross-aged peer mentoring in the learning environment. International Journal of Humanities, Arts and Social Sciences, 4(2), 67-84. doi:https://doi.org/10.20469/ ijhss.4.10003-2

Mbuthia, M. (2013). Perceived factors influencing deviant behaviour among the youth in njathani community, Nairobi, Kenya (Unpublished masters thesis). School of Applied Sciences, Kenyatta University, Nairobi, Kenya.

McIver, M. C., Kearns, J., Lyons, C., \& Sussman, M. (2009). Leadership: A McREL report prepared for stupski foundation's learning system. Retrieved from https://bit.1y/2Y81wIl 
McKee, G. J., Rivkin, S. G., \& Sims, K. R. (2010). Disruption, achievement and the heterogeneous benefits of smaller classes (Technical report). National Bureau of Economic Research, Cambridge, MA.

Merriam, S. B., \& Tisdell, E. J. (2015). Qualitative research: A guide to design and implementation. New York, NY: John Wiley \& Sons.

Nayak, P. B. (2010). India's economy and growth: Essays in honour of VKRV Rao. London, UK: Sage Publications India.

Osalusi, A., \& Oyinloye, B. (2014). Minimizing the rate of students' deviant behaviors through instruction in social studies in Ekiti and Ondo States (Unpublished master's thesis). Department of Curriculum Studies Ekiti State University, Ado-Ekiti, Nigeria.

Ostrosky, M., Jung, E., Hemmeter, M., \& Thomas, D. (2003). Helping children understand routines and classroom schedules: What works briefs. New York, NY: Education Resources Information Center.

Peris, T. S., \& Emery, R. E. (2004). A prospective study of the consequences of marital disruption for adolescents: Predisruption family dynamics and postdisruption adolescent adjustment. Journal of Clinical Child and Adolescent Psychology, 33(4), 694-704. doi:https://doi.org/10.1207/s15374424jccp3304_5

Pizzuro, S. (2001). The individuals with disabilities education act and the nature of American politics: A handbook on public policy. London, UK: ERIC.

Rao, B. (2011). The role of family in child development VIS-A-VIS child in conflict with law-an indian perspective. Guntur, India: Guntur Press.

Regev, A., Berho, M., Jeffers, L. J., Milikowski, C., Molina, E. G., Pyrsopoulos, N. T., ... Schiff, E. R. (2002). Sampling error and intraobserver variation in liver biopsy in patients with chronic HCV infection. The American Journal of Gastroenterology, 97(10), 2614-2618. doi:https://doi.org/10.1111/j.1572-0241.2002.06038.x

Santrock, J. W. (2017). Educational psychology. New York, NY: McGraw-Hill Education.

Seunarinesingh, K. (2011). School administrators' discursive positioning in talk about deviant high school students. Pragmatics, 21(1), 127-144. doi:https://doi.org/10.1075/prag.21.1.07seu

Shellard, E. (2002). Recognizing and preventing bullying. Arlington, VA: Educational Research Service.

Suwanwong, A. (2017). Proactive professional networking strategies for enhancing teacher engagement in private school: Case study of Kraiumnuayvittaya army sponsor school. Journal of Advanced Research in Social Sciences and Humanities, 2(2), 96-102. doi:https://doi.org/10.26500/jarssh-02-2017-0203

Velez, A. M. (2008). Evaluating research methods: Assumptions, strengths, and weaknesses of three educational research paradigms. London, UK: Academic Exchange Extra.

Wahlstrom, K., Seashore, K., Leithwood, K., \& Anderson, S. (2010). Investigating the links to improved student learning: Executive summary of research findings. Retrieved from https : //bit. 1y/2BeYNRz

West Ed. (2008). Effective principals for California schools: Building a coherent leadership development system. Retrieved from https://bit.1y/3d3VbPS 